Chirurgia (2018) 113: 430-435

No. 3, May - June

Copyright@ Celsius

http://dx.doi.org/10.21614/chirurgia.113.3.430

\title{
Surgical Treatment of a Mucinous Cystic Neoplasm in a Young Female Patient - A Case Report
}

\author{
Cristina Radu' ${ }^{1,2}$, Cezar Stroescu ${ }^{1,2}$, Dragoș Chiriță" ${ }^{1}$, Radu Poenaru' ${ }^{1}$, Adelina Birceanu ${ }^{2,3}$, Narcis Copcă ${ }^{1,2}$ \\ ${ }^{1} 2^{\text {nd }}$ General Surgery Clinic, Sfânta Maria Clinical Hospital, Bucharest, Romania \\ ${ }^{2}$ Carol Davila University of Medicine and Pharmacy, Bucharest, Romania \\ ${ }^{3}$ Department of Pathology, Sfânta Maria Clinical Hospital, Bucharest, Romania
}

Corresponding author:

Cristina Radu, MD, PhD Student.

Gastroenterology specialist.

Carol Davila Carol Davila University

of Medicine and Pharmacy

"Sfânta Maria" Clinical Hospital

37-39 blvd. Ion Mihalache

Bucharest, Romania

E-mail: cristinaelena.radu@gmail.com
Received: 22.04 .2018

Accepted: 26.05 .2018

\section{Rezumat}

Tratamentul chirurgical al unui neoplasm mucinos chistic la o femeie tânără

Principala provocare în evaluarea neoplasmelor chistice pancreatice o reprezintă identificarea leziunilor cu potențial malign sau cu criterii de malignitate. Per total, riscul de malignitate al chisturilor pancreatice descoperite întâmplător este mic. Leziunile chistice cu potențial malign includ: chistadenoamele seroase, neoplasmele chistice mucinoase $(\mathrm{MCN})$, neoplasmele papilare mucinoase intraductale (IPMN), neoplasmele solide pseudopapilare. Riscul de dezvoltare a malignității este foarte scăzut pentru chistadenoamele seroase, moderat-crescut în cazul neoplasmelor chistice mucinoase, al tumorilor solide pseudopapilare şi al unor IPMN-uri (pana la 70\% pentru IPMN-urile de duct principal). Prezentăm cazul unei paciente în vârstă de 35 de ani, fără factori de risc semnificativi pentru apariția cancerului de pancreas, diagnosticată clinic şi imagistic cu leziune chistică de corp şi coadă de pancreas, cu diametrul de $7 \mathrm{~cm}$, în contextul unei simptomatologii de obstructie digestivă înaltă, cu durere de etaj abdominal superior, fără ameliorarea simptomelor după tratament conservator. Astfel, s-a realizat pancreatectomie distală, cu evoluție postoperatorie favorabilă. Examenul histopatologic a descris neoplasm mucinos chistic, non-invaziv, cu displazie de grad scăzut. Multe chisturi pancreatice pot fi urmărite imagistic, printr-un algoritm ce combină examinarea CT, RMN sau ecoendoscopică. Decizia de a recomanda tratamentul chirurgical ar trebui să țină cont de factori cum ar fi vârsta pacientului, starea 
generală de sănătate, riscul de malignitate al fiecărei leziuni în parte, potențialele complicații şi gradul de suspiciune de trasformare malignă.

Cuvinte cheie: chist pancreatic, potențial malign, rezecție pancreatică

\begin{abstract}
The major challenge in the evaluation of pancreatic cystic neoplasms is identifying lesions with malignant potential or signs of malignancy. Overall, the risk of malignancy in incidentally detected pancreatic cysts is low. Pancreatic cystic neoplasms with malignant potential are: serous cystic tumors (SCTs), mucinous cystic neoplasms (MCNs), intraductal papillary mucinous neoplasms (IPMNs) and solid pseudopapillary neoplasms (SPNs). The risk for developing malignancy is very low for SCTs, moderate to high in MCNs, solid pseudopapillary tumors and some IPMNs (up to 70 percent for main-duct IPMNs). We present a thirty-five years old female patient, without risk factors for the occurrence of pancreatic cancer was diagnosed via clinical examination and crosssectional imaging of the abdomen with a $7 \mathrm{~cm}$ cystic lesion located in the pancreatic body and tail, in the context of gastric outlet obstruction and upper abdominal pain with no improvement following conservative treatment. A distal pancreatectomy was thus performed, with favorable postoperative outcome. The histopathology examination described a non-invasive mucinous cystic neoplasm with low grade dysplasia. Many pancreatic cysts can be followed with surveillance imaging, through an algorithm which combines CT scan, MRI or endoscopic ultrasound. The decision to recommend surgery should take into account factors such as the patient's age and general health, the malignant risk of the specific lesion, potential complications and the suspicion for malignancy.
\end{abstract}

Key words: pancreatic cyst, malignant risk, pancreatic resection

\section{Introduction}

Most pancreatic cystic neoplasms (PCNs) are detected incidentally when abdominal imaging is performed for other indications (1). PCNs are categorized using the World Health Organization histological classification (2). There are four subtypes of PCNs, which have varying malignant potential: serous cystic tumors, mucinous cystic neoplasms (MCNs), intraductal papillary mucinous neoplasms (IPMNs) and solid pseudopapillary neoplasms. Overall, the risk of malignancy in incidentally detected pancreatic cysts is low. Serous cystic tumors are at very low risk for developing malignancy, whereas the risk is moderate to high in mucinous cystic neoplasms, solid pseudopapillary tumors, and some intraductal papillary mucinous tumors of the pancreas.

Many patients with pancreatic cysts are asymptomatic; when symptoms are present, they are often nonspecific. The major challenge in the evaluation of pancreatic cystic neoplasms is identifying lesions with malignant potential or signs of malignancy while not subjecting patients to unnecessary testing. Cross-sectional imaging (MRI with magnetic resonance cholangiopancreatography or a dedicated pancreatic protocol CT scan) is obtained to determine if there are features present that can identify the specific cyst type and to determine if there are any findings that increase the risk of malignancy (large cyst $>3 \mathrm{~cm}$, a solid component within the cyst, main pancreatic duct dilation).

Many pancreatic cysts can be followed with surveillance imaging. In general, surgery is indicated for cysts with positive cytology, cysts causing complications (eg, pancreatitis), cysts with features concerning for malignancy and cysts with significant malignant potential. 


\section{Case report}

We present the case of a 35 years old female, complaining of early satiety, postprandial vomiting after solid meals and left upper quadrant abdominal pain, symptoms that began 4 months before seeking medical care. The patient had no personal or family history of acute or chronic pancreatitis, pancreatic cancer or other malignancies. She consumes alcohol on an occasional basis ( $20 \mathrm{~g} /$ week) and has never smoked. She doesn't have diabetes mellitus and her BMI is normal $\left(23.7 \mathrm{~kg} / \mathrm{m}^{2}\right)$.

She described early satiety, nausea and vomiting, approximately one hour after solid meals. Her pain was continuous, diurnal and nocturnal, of constant moderate intensity, it radiated to the back and was not relieved by usual analgesics (metamisole, acetaminophen). It was not influenced by meals or bowel movements. She didn't report any weight loss.

On clinical examination, at the time of admission (January 2017): normal skin color, normal body temperature, abdominal tenderness to palpation of the left upper abdominal quadrant, no signs of peritoneal irritation, no palpable mass. Blood tests: normal blood count, normal liver tests (ALT, AST, total bilirubin, yGT, alkaline phosphatase), no coagulopathy, normal serum lipase. Her viral markers (HBs antigen and antiHCV antibodies) were negative and the tumoral markers CEA and CA 199 were within the normal range.

An abdominal ultrasound was performed and described a cystic lesion located in the body and tail of the pancreas, in contact with the posterior gastric wall. The lesion was 7.1/6.4 $\mathrm{cm}$ in diameter, round, with thin, regular wall, multilocular, unique. No signs of chronic or acute pancreatitis were seen. The Wirsung duct didn't appear dilated. A contrastenhanced MRI of the abdomen and pelvis was then recommended and showed the above mentioned cyst, of $7 / 6.5 \mathrm{~cm}$, multiloculated, with internal septa, without thickening of the wall, no internal solid component or mass, with calcification of the cyst wall and gastric compression (Figs. 1, 2).

The upper gastrointestinal endoscopy

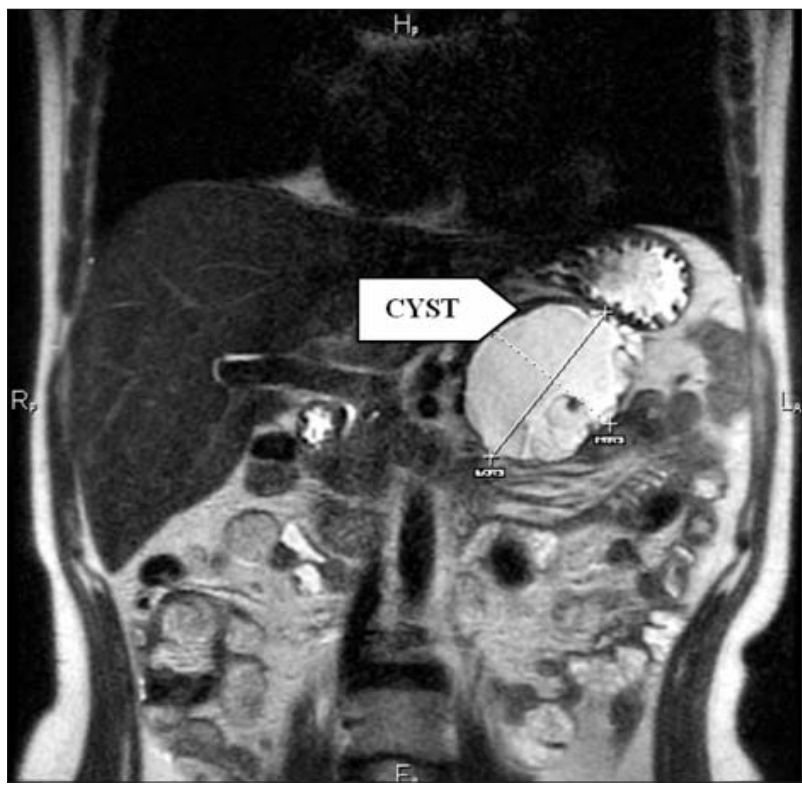

Figure 1. T2 coronal MRI - multilocular cystic lesion of the pancreatic body and tail

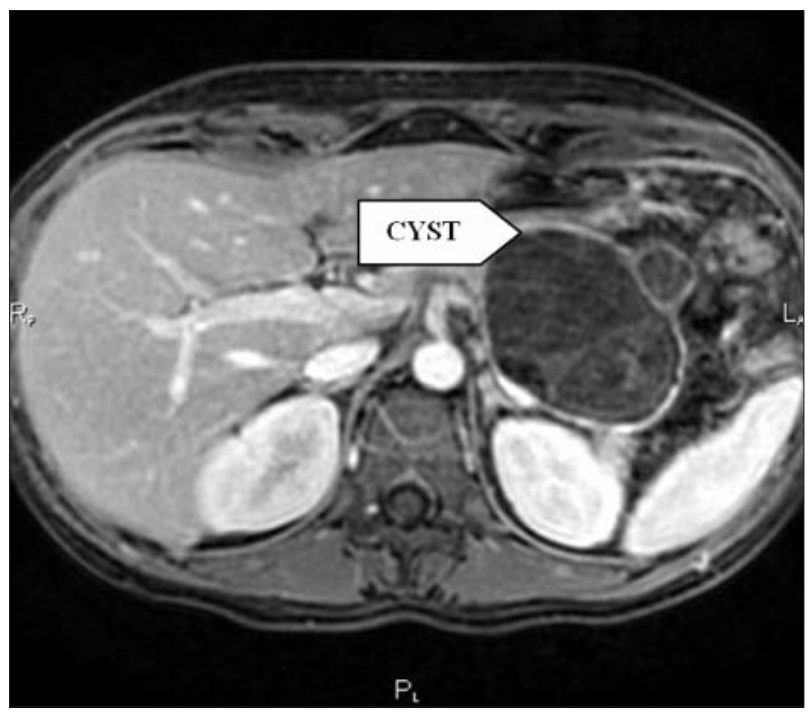

Figure 2. Axial contrast enhanced MRI - multilocular cystic lesion of the pancreatic body and tail

showed signs of extrinsic compression of the posterior gastric body wall, with normal overlying mucosa.

Due to the presence of some risk factors suggestive for malignancy (cyst size $>3 \mathrm{~cm}$, wall calcification) and to the fact that the patient had difficult to control gastric outlet obstruction symptoms, we decided to recommend surgical therapy. On January 10 2017, 
surgery was performed and a cystic tumor of the pancreatic tail was found, adherent to the splenic vein. The patient had a distal pancreatectomy, with peritoneal drainage (Fig. 3). The postoperative evolution was favorable with resumption of food tolerance and intestinal transit and suppression of the drainage tubes at day 4.

The pathology report described a 7/6.4/3 cm multilocular cystic lesion with smooth external and internal surface, with trabeculated and thickened walls and mucoid content. The cyst was lined with columnar epithelium, with low grade dysplasia, complex papillae with pancreaticobiliaary pattern lined by cuboidal cells with prominent nucleoli, with subepithelial ovarian stroma, mucinous content and marked fibrosis and dystrophic calcifications of the cyst wall (Fig. 4). The surrounding pancreatic tissue also showed marked interstitial fibrosis. In the adipose tissue, two reactive lymph nodes were found. The conclusion was of non-invasive mucinous cystic neoplasm, with low-grade dysplasia (Fig. 5).

A one-month postoperative physical examination was performed along with blood tests and an ultrasound exam. No significant findings were noted.

\section{Discussion}

Very often pancreatic cysts are discovered incidentally when abdominal imaging is obtained for unrelated indications.

Mucinous cystic neoplasms can present with abdominal pain, recurrent pancreatitis, gastric outlet obstruction, and/or a palpable mass (3). Jaundice and/or weight loss are more common with malignant lesions.

Contrast-enhanced CT or MRI are the tests of choice to diagnose MCNs. MCNs classically appear as a septated cystic lesion, like in our patient, although they can be unilocular (4). They may contain eccentric calcifications, seen in up to 15 percent of patients (5).

Findings associated with malignant transformation in MCNs include (6): larger size (5 $\mathrm{cm}$ or larger in one series (6)), a thickened or irregular cyst wall, an internal solid

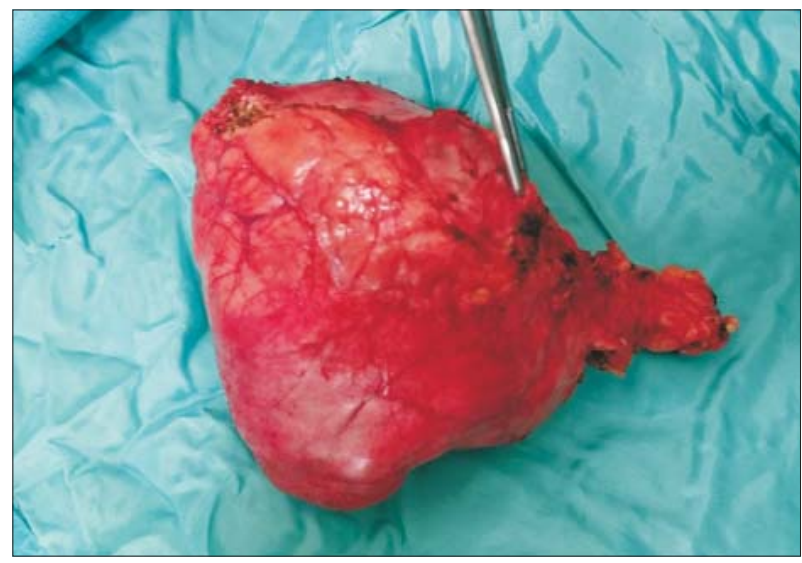

Figure 3. Cyst of the pancreatic body and tail, postoperative aspect

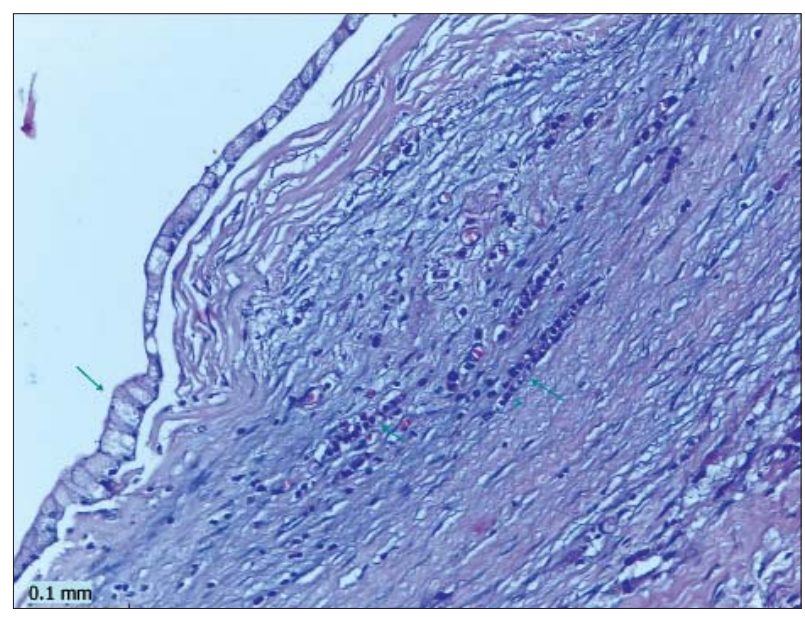

Figure 4. Hematoxylin eosin $20 \times$ magnification. Cyst wall with numerous plasma cells and fibrosis lined by tall mucin-producing cells

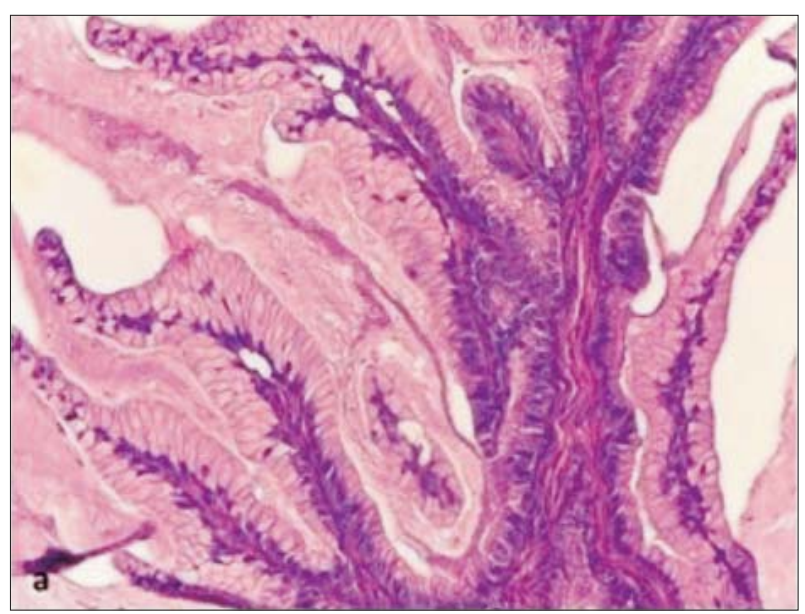

Figure 5. Hematoxylin eosin $20 \times$ magnification. Dense cellular ovarian-type stroma and papillae lined by tall mucinproducing cells with low grade dysplasia, without invasion 
component or mass, possible calcification of the cyst wall.

The optimal approach to evaluating pancreatic cysts is unclear. In 2015, the American Gastroenterological Association (AGA) published new guidelines on the evaluation and management of pancreatic cysts (7).

In some cases, resection will be indicated based on the findings from cross-sectional imaging alone (eg, if a main-duct IPMN or a SPN is diagnosed) or because the cyst is causing complications (eg, pancreatitis), so additional evaluation will not be necessary.

For patients who do not have an indication for resection based on cross-sectional imaging alone, additional evaluation may be recommended by endoscopic ultrasound with fine-needle aspiration (EUS FNA) in cysts $>1.5 \mathrm{~cm}$ in size and for lesions with worrisome features like solid component within the cyst, main pancreatic duct $>0.5 \mathrm{~cm}$ in size, symptoms related to the cyst, family history of pancreatic cancer (8).

In the case of MCNs, EUS FNA will show that the fluid aspirated from the cyst is typically viscous. Cytology may reveal columnar cells with varying levels of atypia. Aspirates taken from solid components within the cyst have a high yield for malignancy. Staining for mucin is positive in $<50$ percent. The CEA level is typically high (>200 ng/mL).

From a histopathological point of vue, the ovarian stroma is extremely common and an entity-defining feature for mucinous cystic neoplasms, to an extent that it has almost become a requirement for the diagnosis (9). The distinction between MCNs and IPMNs is important in clinical practice because they have different biologic behaviour and pathologic features, including presence of invasiveness, recurrence rate and multifocality (9).

The ovarian stroma of the pancreatic mucinous cyst suggests two hypotheses regarding this origin. The first hypothesis is that these neoplasms arise from rests of embryologic ovarian tissue located in the pancreas. The second hypothesis proposed to account for these neoplasms is that the stroma represents a recapitulation of periductal fetal mesenchyme, the primitive mesenchyme seen around the pancreatic and hepatic ducts in the developing fetus (10). Regardless of its origin, this stroma is hormone sensitive; it is often admixed with luteal-type cells and it regularly expresses progesterone receptors. Some mucinous cystic neoplasms are reported to be associated with ovarian thecomas, suggesting a hormone influence in the pathogenesis of these neoplasms (11).

In our case, the patient was young, in good medical condition, with a symptomatic pancreatic cyst with some worrisome features (large size, calcification of the wall). After explaining the benefits and the risks of surgery, a mutual decision was made, in favor of the surgical therapy.

If surgery is performed, lesions in the body or tail of the pancreas require a distal pancreatectomy, whereas those in the head of the gland are resected by pancreaticoduodenectomy.

MCNs have significant malignant potential. In two series, each with 56 patients with $\mathrm{MCNs}$, carcinoma (noninvasive plus invasive) was present in 11 and 38 percent, respectively $(12,13)$. The prognosis is excellent if the MCN is removed prior to invasion. As a result, resection is recommended for MCNs in patients with acceptable surgical risk.

Alternative treatments are also being studied, including endoscopic cyst ablation methods in which the cyst is injected with ethanol or chemotherapeutic agents during EUS (14-16). These techniques may hold promise for the treatment of symptomatic cysts or cysts with malignant potential. However, the safety and efficacy of these approaches continues to be examined. For now, they may only be recommended in patients that are not surgical candidates.

For patients who undergo cyst resection, follow-up depends on the pathologic findings. If there is evidence of invasive cancer or highgrade dysplasia, magnetic resonance imaging surveillance of the remaining pancreas should be performed every two years (7). If there is no high-grade dysplasia or malignancy, surveillance is not needed for patients who do not have papillary mucinous neoplasms (IPMN) 
or a strong family history of pancreatic cancer, like in our case.

\section{Conclusion}

The optimal approach to evaluation and management of pancreatic cystic neoplasms will likely be refined as more data become available in the future. Cysts with malignant potential include MCNs, IPMNs, and SPNs. There is little to no malignant potential with serous cystic tumors.

Many pancreatic cysts can be followed with surveillance imaging. In general, surgery is indicated for cysts with positive cytology, cysts causing complications (eg, pancreatitis, upper digestive tract obstruction), cysts with features suggestive for malignancy and cysts with significant malignant potential.

\section{Disclosure}

No author has any conflict of interest.

\section{References}

1. Spinelli KS, Fromwiller TE, Daniel RA, Kiely JM, Nakeeb A, Komorowski RA, et al. Cystic pancreatic neoplasms: observe or operate. Ann Surg. 2004;239(5):651-7; discussion 657-9.

2. World Health Organization Classification of Tumours. Pathology and Genetics of Tumours of the Digestive System, Aaltonen LA, Hamilton SR (Eds), IARC Press, Lyon, France 2000.

3. Sharma, A. Tumors of the Pancreas. In: Current Diagnosis \& Treatment: Gastroenterology, Hepatology, \& Endoscopy, Greenberger, NJ, Blumberg, RS, Burakoff, R (Eds), McGraw-Hill, New York 2009. p.318

4. Gress F, Gottlieb K, Cummings O, Sherman S, Lehman G. Endoscopic ultrasound characteristics of mucinous cystic neoplasms of the pancreas. Am J Gastroenterol. 2000;95(4):961-5.
5. Sarr MG, Carpenter HA, Prabhakar LP, Orchard TF, Hughes S, van Heerden JA, et al. Clinical and pathologic correlation of 84 mucinous cystic neoplasms of the pancreas: can one reliably differentiate benign from malignant (or premalignant) neoplasms? Ann Surg. 2000;231(2):205-12.

6. Reddy RP, Smyrk TC, Zapiach M, Levy MJ, Pearson RK, Clain JE, et al. Pancreatic mucinous cystic neoplasm defined by ovarian stroma: demographics, clinical features, and prevalence of cancer. Clin Gastroenterol Hepatol. 2004; 2(11):1026-31.

7. Vege SS, Ziring B2, Jain R3, Moayyedi P4; Clinical Guidelines Committee; American Gastroenterology Association. American gastroenterological association institute guideline on the diagnosis and management of asymptomatic neoplastic pancreatic cysts. Gastroenterology. 2015; 148(4):819-22; quize12-3.

8. Khalid A, Brugge W. ACG practice guidelines for the diagnosis and management of neoplastic pancreatic cysts. Am J Gastroenterol. 2007;102(10):2339-49. Epub 2007 Aug 31.

9. Tanaka M, Chari S, Adsay V, Fernandez-del Castillo C, Falconi M, Shimizu M, et al. International consensus guidelines for management of intraductal papillary mucinous neoplasms and mucinous cystic neoplasms of the pancreas. A consensus of the Working Group of the International Association of Pancreatology. Pancreatology. 2006;6 (1-2):17-32.

10. Khalifeh I, Qureshi F, Jacques S, et al. The nature of 'ovarian-like' mesenchyme of pancreatic and hepatic mucinous cystic neoplasms: A recapitulation of the periductal fetal mesenchme? (Abstract). Modern Pathol 2004;17.

11. Colović R, Barisić G, Colović N, Marković V, Nadj G. Double mucinous cystadenoma of the pancreas associated with thecoma of the ovary. Acta Chir lugosl. 2002;49(1):95-7.

12. Zamboni G, Scarpa A, Bogina G, lacono C, Bassi C, Talamini G, et al. Mucinous cystic tumors of the pancreas: clinicopathological features, prognosis, and relationship to other mucinous cystic tumors. Am J Surg Pathol. 1999;23(4):410-22.

13. Reddy RP, Smyrk TC, Zapiach M, Levy MJ, Pearson RK, Clain JE, et al. Pancreatic mucinous cystic neoplasm defined by ovarian stroma: demographics, clinical features, and prevalence of cancer. Clin Gastroenterol Hepatol. 2004; 2(11):1026-31.

14. Gan SI, Thompson CC, Lauwers GY, Bounds BC, Brugge WR. Ethanol lavage of pancreatic cystic lesions: initial pilot study. Gastrointest Endosc. 2005;61(6):746-52.

15. Oh HC, Seo DW, Lee TY, Kim JY, Lee SS, Lee SK, et al. New treatment for cystic tumors of the pancreas: EUS-guided ethanol lavage with paclitaxel injection. Gastrointest Endosc. 2008;67(4): 636-42.

16. Oh HC, Seo DW, Song TJ, Moon SH, Park DH, Soo Lee S, et al. Endoscopic ultrasonography-guided ethanol lavage with paclitaxel injection treats patients with pancreatic cysts. Gastroenterology. 2011;140(1):172-9. 